\title{
The Politics of Time: Epistemic Shifts and the Reception History of the Four Kingdoms Schema
}

\author{
Brennan Breed
}

Time is a particularly slippery object of study. ${ }^{1}$ As a structuring element of human experience, it lies outside the bounds of our direct perception; nevertheless, we cannot help but observe its constant, omnipresent effects. Since time is in itself imperceptible, we observe and measure it only by its impacts. ${ }^{2}$ Moreover, since time appears to be ubiquitous, any division of time will necessarily be arbitrary. Yet in order to conceive of time, we must make such arbitrary distinctions. As systems-theoreticians G. Spencer-Brown and Niklas Luhmann have demonstrated, the drawing of distinctions, of delimitation and articulation, must precede any and every act of indication or description. ${ }^{3}$ Time is a particularly rich index of the necessity of articulation precisely because of its simultaneous ubiquity and imperceptibility.

Thinking about time requires us to study changes in objects that reveal the passage of time, which in turn requires us to articulate different moments in time by which to measure that change. Periodization is the always-constructive act of articulating time into different, distinguishable objects for purposes of measurement and analysis. Even the articulation of a period of time as seemingly natural as a day is a constructive act of periodization. Not only is a twenty-four hour cycle arbitrary from any cosmic perspective other than that of the earth: even within the limits of an anthropocentric perspective, various cultures begin and end their counting of days at different moments. ${ }^{4}$ Some start with daybreak, others nightfall, while still others switch from one day to

1 W. H. Newton-Smith, The Structure of Time (London: Routledge \& Kegan Paul, 1980), 1-4.

2 For a general introduction to the analysis of time, see Carlo Rovelli, The Order of Time, trans. S. Carnell and E. Segre (New York: Riverhead, 2018).

3 As Spencer-Brown writes, "We cannot make an indication without drawing a distinction" (Laws of Form [London: George Allen \& Unwin, 1969], 1). Luhmann and Spencer-Brown helpfully point out the radical contingency of distinctions and their incommensurability when compared. See Nicholas Luhmann, "Kultur Als Historischer Begriff," in Gesellschaftsstruktur und Semantik: Studien zur Wissenssoziologie der modernen Gesellschaft: Band 4 (Frankfurt: Surhkamp, 1995), 40-47.

4 For an overview, see Leofranc Holford-Strevens, The History of Time: A Very Short Introduction (Oxford: Oxford University Press, 2005), 1-17. 
another at a fairly arbitrary moment in the midst of the night. There is no objectively correct way to articulate a day, because the time period of a day does not pre-exist its articulation.

Yet if one wants to think of change, to identify and organize a narrative account of anything, or to try and conceive of anything spanning various moments of change, then one must articulate time. All of these acts are constructive, and all function according to different logics. In his influential book L'Ordre du Temps, Krzysztof Pomian discerns "four ways of visualizing time, of translating it into signs" and manipulating it. ${ }^{5}$ The first category Pomian names is "chronometry," which refers to the quantitative practice of measuring temporal intervals, such as days, weeks, and years, generally with reference to natural cycles of light, but sometimes to cultural occurrences like the Greek Olympiads. Second, Pomian distinguishes "chronography," the basic, qualitative annalistic description of events and facts as observed in time, like a chronicle that tends to focus on human activity and human agents. Chronology describes the ordering and synchronizing chronography within a chronometrical frame: that is, the charting of events correctly within the measure of days, months, and years in a serial fashion. Chronology is thus the first step in the narration of time, and it can include the subdivision of time into periods.

Pomian finally distinguishes a fourth sense of time, which he names chronosophy. He explains that chronosophy is the

integration of the past, the present and the future of an object under study into one image, or a description of its future, in order to complete its past and present. Every chronosophy is therefore dependent upon some procedure supposed to predict the future, sometimes a very distant one, with a reasonable if not absolute certainty. The essential questions of every chronosophy are either those of intelligibility or those of meaning of particular events (or facts) of some segment of history or the history taken as a whole. ${ }^{6}$

Chronosophy is thus the articulation of history's "purpose" that is generally identifiable with "an agent acting purposefully," like God, or the Weltgeist, or

5 Krzysztof Pomian, L'ordre du temps, Bibliothèque des Histoires (Paris: Gallimard, 1984). See also Krzysztof Pomian, "Astrology as a Naturalistic Theology of History," in "Astrologi Hallucinati:" Stars and the End of the World in Luther's Time, ed. Paola Zambelli (Berlin: Walter de Gruyter, 1986), 29-43; Krzysztof Pomian, "La crise de l'avenir," Le Débat 7 (1980): 5-17, reprinted in Sur l'histoire (Paris: Gallimard, 1999), 233-62.

6 Pomian, "Astrology," 29. 
the psychology of human agents. ${ }^{7}$ Any theology or philosophy or psychology of history that tries to find meaning of history itself, or a structure and thus significance within history itself, is an effort of chronosophy. Thus chronosophy is not simply the narration of time, but it is the synthesis of multiple narratives into a larger meaning. Pomian's categories helpfully disentangle different modes of time-representation and allow for more careful comparative and analytical work.

The articulation, organization and conceptualization of time is a powerful act, and is thus often explicitly a political act. In the ancient Near East, for instance, we can find evidence of politically and ritually inflected chronometry that adumbrates the cycles of nature, such as the annual Akitu festival. ${ }^{8}$ In the Hebrew Bible, the chronological location of events is often measured in terms of political leaders (e.g., Amos 1:1), even after the time of local monarchies (e.g., Ruth 1:1; Hosea 1:1; Neh 12:47; 1 Chron 3:13; 5:10), and much of the chronological recording of events in the ancient Near East takes the form of royal annals constructed for the administration of the king. ${ }^{9}$

In the Hebrew Bible, we can also see evidence of sophisticated political chronosophies, most clearly in the compilation of the Torah and Deuteronomistic History that begins with creation and ends with the destruction of Israel and Judah. ${ }^{10}$ This required many separate narratives to be synthesized and organized into one contemporaneous framework. ${ }^{11}$ But the book of Daniel is also

7 Pomian, "Astrology," 29-30.

8 See Julye Bidmead, The Akitu Festival: Religious Continuity and Royal Legitimation in Mesopotamia (Piscataway: Gorgias, 2014).

9 See Mette Bundvad, "Defending the Concept of Time in the Hebrew Bible," sJot 28 (2014): 278-95; Gershon Brin, The Concept of Time in the Bible and the Dead Sea Scrolls, STDJ 39 (Leiden: Brill, 2001); note Bundvad's discussion of Sacha Stern, Time and Process in Ancient Judaism (Oxford: Littman Library of Jewish Civilization, 2003) in Bundvad, "Defending the Concept of Time," 282-93.

10 See Marc Brettler, "Cyclical and Teleological Time in the Hebrew Bible," in Time and Temporality in the Ancient World, ed. R. M. Rosen (Philadelphia: University of Pennsylvania Museum of Archaeology and Anthropology, 2004), 111-28.

11 See the discussion of Alfred Gell's statement that time "allows for the co-ordination of diverse processes; biological processes with social ones, psychological or subjective processes with objective, clock-timed ones, and so forth," in Bundvad, "Defending the Concept of Time," 292, quoting from Alfred Gell, The Anthropology of Time: Cultural Constructions of Temporal Maps and Images (Oxford and Dulles, VA: Berg, 1992), 316. Also note Robert Kawashima's discussion of "Zielinski's law" in Biblical Narrative and the Death of the Rhapsode, ISBL (Bloomington: Indiana University Press, 2004), 129-59. Zeilinski's law consists of the observation that Homer never depicts events occurring simultaneously, at the same time- that is, Homer's narrative clock never stops ticking, as opposed to the biblical narratives, which often set several storylines in contemporaneous frameworks that are tied together with literary devices such as flashbacks. 
notable for its intense interest in all four modes of representing time, including the marking and counting of days and blocks of ritual time (e.g., Daniel 9), its careful annalistic recounting of Hellenistic history (e.g., Daniel 10-12) and its intense fascination with chronology and the ordering of events. ${ }^{12}$ But perhaps the most defining characteristic of the book of Daniel, as well as its reception history, is its distinctive chronosophy, epitomized in the four kingdoms schema of chapters 2 and 7: namely, a theology of history that focuses on ultimate divine control over the cosmos with a particular emphasis on the periodization of unjust political sovereigns.

Politicized chronosophy is not unique to the ancient Near East. As Dipesh Chakrabarty and Kathleen Davis have argued, dominant political powers throughout history consistently define and organize periods of time to consolidate their power, especially over groups that they consider "others." In his book Provincializing Europe, Chakrabarty explains that the European narrative of secularization enabled the colonial project through its use of "historical time as a measure of the cultural difference" between Europe's center and the colonial periphery. ${ }^{13}$ Kathleen Davis's monograph Periodization and Sovereignty analyzes the political uses of historical periodization, and in particular the distinction between mediaeval and modern periods. Davis argues that the scholarly concepts of feudalism and secularization emerge from arguments about the nature of political sovereignty precisely as a justifying tool for colonialism. As Davis writes, "the history of periodization is juridical, and it advances through struggles over the definition and location of sovereignty."14 Davis notes that periodization remains a powerful tool of sovereign power in both center and periphery even today.

The development of the four kingdoms schema throughout history demonstrates the diverse political effects of chronosophical constructions, as it has been one of the most influential time-structuring devices ever employed.15 Moreover, it has often been the site of contestation, usually of a political nature, over the nature of time-structuring devices themselves. The four kingdoms

12 See Samuel Ballentine, "The Future Beyond the End: Lessons from History by Herodotus and Daniel," PRSt 43 (2016): 145-59; Paul Niskanen, The Human and the Divine in History: Herodotus and the Book of Daniel, JSOTSup 396 (London: T\&T Clark, 2004).

13 Dipesh Chakrabarty, Provincializing Europe: Postcolonial Thought and Historical Difference (Princeton: Princeton University Press, 200o), 6.

14 Kathleen Davis, Periodization and Sovereignty: How Ideas of Feudalism and Secularization Govern the Politics of Time (Philadelphia: University of Pennsylvania Press, 2008), 6.

15 See Brennan Breed, "Daniel's Four Kingdoms Schema: A History of Re-writing World History," Int 71 (2017): 178-89; Carol A. Newsom, "Rhyme and Reason: The Historical Résumé in Israelite and Early Jewish Thought," in Congress Volume Leiden 2004, ed. A. Lemaire, VTSup 109 (Leiden: Brill, 2006), 215-33. 
schema is an intriguing test case for understanding the politics of time because the device explicitly focuses on transitions in political sovereignty, control over time and space, and the impact of the past on the unfolding of the future. ${ }^{16}$ It is important to notice that the schema itself does not have a natural or necessary political orientation, as it is put to a variety of uses even before it acquires the different forms that it takes in the book of Daniel. It likely served as political propaganda for several ancient empires. The earliest deployments of this schema are found in the works of Herodotus and Ctesias, historians of the fifth and fourth centuries BCE, who use this order of kingdoms to frame their discussion of the rise of Persia. ${ }^{17}$ While both historians are Greek, the schema bears the marks of Persian royal propaganda-most tellingly, they mention Media instead of Babylon in their historical scheme, which only makes sense from a Persian historical and geographical perspective. Centuries later, Roman historians such as Polybius, Tacitus and Appian would adapt the schema to justify their own city's rapid ascendancy to regional sovereignty. 18

The four kingdoms scheme was also appropriated by at least two groups that lacked sovereignty: Second Temple Jews, as in the Fourth Sybilline Oracle and Tobit, and inhabitants of Asia who imagined that the empire would return from Greece to Persia. ${ }^{19}$ Thus, the four kingdoms schema does not have a necessary political message or predetermined political ends: it is a tool, and like any tool it presents a panoply of potential uses. Elsewhere I have suggested that, after analyzing both text and its hermeneutical trajectories, one can determine a given text's "degrees of mobility," also called "degrees of freedom,"

16 See Carol A. Newsom with Brennan Breed, Daniel: A Commentary, otl (Louisville: Westminster John Knox, 2014), 59-97.

17 Herodotus 1.95, 130, 184; Ctesias, FGrHist 688 F.5. For attempted reconstructions of the origins and transmission of the schema, see David Flusser, "The Four Empires in the Fourth Sibyl and in the Book of Daniel," IOS 2 (1972): 148-75; Joseph Swain, "The Theory of the Four Monarchies: Opposition History under the Roman Empire," CP 35 (1940): 1-21; Arnaldo Momigliano, "The Origins of Universal History," in The Poet and the Historian: Essays in Literary and Historical Biblical Criticism, ed. R. Friedman, Hss 26 (Chico: Scholars Press, 1983), 133-55. For a critique of Swain and Flusser's theory of transmission, see Josef Wiesehöfer, "Vom 'oberen Asien' zur 'gesamten bewohnten Welt': Die hellenistiche-römische Weltreiche-Theorie," in Europa, Tausendjähriges Reich und Neue Welt: Zwei Jahrtausende Geschichte und Utopie in der Rezeption des Danielbuches, ed. Mariano Delgado, Klaus Koch, and Edgar Marsch (Stuttgart: Universitätsverlag Freiburg Schweiz, 2003), 66-83.

18 See Polybius 38.22; Tacitus, Hist. 5.8-9; Appian, Preface 9; Dionysius of Halicarnassus 1.22.4; and the fragment attributed to Aemilius Sura, found in Velleius Paterculus. Note the criticism of Swain's understanding of Sura by Doron Mendels, "The Five Empires: A Note on a Hellenistic Topos," AJP 102 (1981): 330-37.

Swain, "The Theory of the Four Monarchies," 4-12; Flusser, "The Four Empires," 149-54. 
in biblical texts. ${ }^{20}$ I have argued that a point of flexion in the four kingdoms schema emerges for readers based on their social location - to be precise, depending on whether or not they have a share of power in the political order that surrounds them. Daniel's four kingdoms schema provides an intriguing opportunity to see how political, cultural and military power inflects the various readings of sacred texts. ${ }^{21}$

Some scholars have criticized the act of historical periodization. As Frederic Jameson writes, periodization tends to "facile totalization, a seamless web of phenomena which, in its own way, 'expresses' some unified inner truth-a world-view or a period style or a set of structural categories which marks the whole length and breadth of the 'period' in question. Yet such an impression is fatally reductive." $22 \mathrm{He}$ points out both a "synchronic version of the problem: that of the status of the individual period ... and a diachronic one, in which history is seen in some linear way as the succession of such periods, stages, or moments." ${ }^{23}$ As Jameson writes, "[i]ndividual period formulations always secretly imply or project narratives or stories-narrative representationsof the historical sequence in which such individual periods take their place and from which they derive their significance." ${ }^{24}$ For example, the scholarly commonplace in use since the time of Petrarch, namely "Antiquity, Dark Ages, Renaissance," enacts a death-rebirth metaphor that is clearly reductionist.

And yet, this very schema, and many like it, proves helpful, and there is even some truth to it. Thus periodization can be illuminating, but the construction of a historical period also necessarily obscures much that one could otherwise see. Hence, there is an undeniably political aspect to any act of periodization: what to obscure, and what to focalize? Even Jameson agrees with G. Spencer-Brown that, for the purposes of analysis, we must periodize, as it is required for thinking about history. ${ }^{25}$ As Ernst Bloch argues, the question of how to periodize is the point of historiographical work itself, even if we must always note its failures. ${ }^{26}$ Even Jacques Le Goff, whose book titled Must We Divide History Into Periods?, answers in a resounding "yes," nevertheless writes:

20 See Brennan Breed, Nomadic Text: A Theory of Biblical Reception History, ISBL (Bloomington: Indiana University Press, 2014), 161, 168, 182.

21 Breed, "Daniel's Four Kingdoms," 178-89.

22 Fredric Jameson, The Political Unconscious: Narrative as a Socially Symbolic Act (Ithaca: Cornell University Press, 1982), 27.

23 Jameson, Political Unconscious, 28.

24 Jameson, Political Unconscious, 28.

25 Jameson, Political Unconscious, 218.

26 Ernst Bloch, "Nonsynchronism and the Obligation to Its Dialectics," trans. Mark Ritter, New German Critique 11 (1977): 22-38. 
"[t]here is nothing neutral, or innocent, about cutting time up into smaller parts ... periodization is more than a mere collection of chronological units. It contains also the idea of transition ... both the temporal continuity this succession embodies and the rupture of temporal continuity."27

So, for the purposes of this essay, I too must periodize, and accept the severely reductionist problems inherent in the very act. In the limited space I have here, I will sketch the development of the four kingdoms schema in Christian Western Europe from Late Antiquity to Early Modernity, focusing on moments of transition between different conceptions of both time and sovereignty. Future study of Jewish and Muslim interactions with the four kingdoms schema and a survey of Eastern European, Asian, African and American Christian traditions would greatly enrich this argument.

\section{The Four Kingdoms Schema from Ancient Rome to Late Antiquity}

After Rome established unquestionable hegemony over the Mediterranean world in the last century before the Common Era, most Jews and Christians who engaged with Daniel's schema re-identified the fourth kingdom as imperial Rome (Dan 2:40-44; 7:7-11, 23-27; cf. 4 Ezra 12:11-12). In order to maintain the fourfold schema, readers of Daniel 2 and 7 tended to displace the Hellenistic empires from the fourth to the third position, and then combine Media and Persia to both occupy the second kingdom's position in the visions (e.g., Sib. Or. 4.49-101). Jewish and Christian interpreters alike before the fourth century CE respected Rome's power and often adopted many Roman cultural practices, but they nevertheless typically identified Rome as an evil force opposed to the will of God (cf. Hippolytus, Comm. Dan. 4.8; but note moderating positions by Tertullian, Apol. 23, Josephus, Ant. 10.267, and Origen, C. Cels. 6.46). ${ }^{28}$

With the rise of Constantine the Great and his patronage of Christianity in the early fourth century $\mathrm{CE}$, however, many Christians living under the shadow of Rome began to think differently about their political context. Jerome, for example, reinterpreted the significance of the fourth empire in the schema, but still emphasized its weakness and inevitable demise (Expl. Dan. 7.8). Yet others saw Rome as a bridge between the fourth empire and the fifth, unending

27 Jacques Le Goff, Must We Divide History Into Periods?, trans. Malcolm DeBevoise (New York: Columbia University Press, 2017), 2.

28 See also Seth Schwartz, "Rabbinic Culture' and Roman Culture," in Rabbinic Texts and the History of Late-Roman Palestine, ed. Martin Goodman and Philip Alexander (Oxford: Oxford University Press, 2010), 283-99. See also Hayim Lapin, Rabbis as Romans: The Rabbinic Movement in Palestine, 100-40o CE (Oxford: Oxford University Press, 2012). 
kingdom of the "holy ones" (Dan 7:18, 27). Eusebius, in a sermon in praise of Constantine, applied Dan 7:18 ("the holy ones of the Most High shall receive the kingdom") to the transition of Roman imperial power from Constantine to his sons, thus reinterpreting the fourth kingdom as one that transitions seamlessly into the fifth empire of the saints. ${ }^{29}$ In Eusebius's view, the Empire's ruler acknowledged the sovereignty of the true God (cf. Dan 6:26-27), and thus the fourth kingdom had been sanctified, inaugurating a universal peace. The promised future fifth kingdom would then be merely a continuation and spiritualization of this fourth kingdom, which would rule until the end of time.

Christians living in the sphere of Roman power tended to agree with Eusebius's interpretation of Daniel's schema (Cyril, Catech. 15.12; Eusebius, Dem. ev. 25, Lactantius, Inst. 7.16, Victorinus of Pettau, Comm. Apoc. 17.9), though Augustine famously dismissed the importance of the four kingdoms schema and the centrality of the Roman Empire for interpreting sacred history (Civ. 20.23). Jerome's discussion of the four kingdoms in his Daniel commentary became the standard interpretation through the mediaeval period through its adoption in the Glossa Ordinaria (Expl. Dan. 1.2.31-35; 2.7.8), yet it was Paulus Orosius, a Spanish priest mentored by Augustine but also influenced by Jerome, who defined the Latin Christian interpretation of Daniel's schema for the next millennium. Orosius wrote a history "against the pagans" in $416 \mathrm{CE}$ at Augustine's request, but he decided to side with Jerome on the status of the Roman Empire and the central importance of the four kingdom schema for understanding history. ${ }^{30}$ Like Jerome, Orosius was not shy about equating the progress of the Roman Empire with God's providential activity in history, which (he claimed) would last until the end of time. As Jennifer Harris argues, Orosius presents the "first real attempt at a world history using documentary sources and presenting an argument for the meaning of history," and it was remarkably influential likely because of that fact. ${ }^{31}$ The German migrations and decomposition of Roman imperial control over Western Europe

29 See Gerhard Podskalsky, Byzantinische Reichseschatologie: Die Periodisierung der Weltgeschichte in den vier Grossreichen (Dan 2 und 7) und dem tausendjährigen Friedensreiche (Apok. 2o) (Munich: Fink, 1972), 11-13, and Gerbern S. Oegema, Early Judaism and Modern Culture: Literature and Theology (Grand Rapids: Eerdmans, 2011), 162-63.

30 Augustine strove to keep sacred and secular history separate after the disappointment of the fall of Rome for many Christians who had pinned their theological hopes on the Empire's power. But over time, political Augustinianism re-assimilated secular history to the sacred story, and by the twelfth century, Otto of Friesing writes that his secular history only focuses on one city, the City of God, since all emperors and subjects after Constantine are Christian. See Le Goff, Must We Divide History, 33.

31 Jennifer Harris, "The Bible and the Meaning of History in the Middle Ages," in The Practice of the Bible in the Middle Ages: Production, Reception, and Performance in Western 
tested Christian faith in the theory that Rome, and Christian imperial power, would survive until the end of time. In the Roman East, of course, the continuing Roman Empire controlled by Constantinople did not face this theological quandary.

Even so, the multiple Christian and pagan kingdoms that emerged in Europe and North Africa in the fifth and sixth centuries were obviously not one universal empire, and the seeming end of Roman power proved a theological and political puzzle. Orosius presented one potential solution to the problem, and opened the possibility of identifying the Roman Empire with diverse Christian polities. That is, the Christian religion itself soon emerged as a symbolic, spiritual "empire of Christ" that claimed the allegiance of diverse ethnicities (Goths, Franks, Britons, etc.) and replaced the concrete and unified political universality of the former Roman Empire. Thus the sacred history of the Church continued unbroken; Rome's political-theological dominion and the concept of "Christian lands" spanned from the Atlantic to Persia. ${ }^{32}$ Other attempts to identify Rome's demise with the rise of another concrete political entity as the fifth kingdom that superseded Rome-such as the Vandals, as presented in the late fifth-century Arian recension of the Donatist Liber genealogus - proved less influential over time. ${ }^{33}$ In Western Europe during the fifth and sixth centuries $\mathrm{CE}$, new conceptions of space and time made the Orosian model more powerful, and the innovation of translatio imperii ("translation of empire") required these conceptual shifts to function.

Orosius's synthesis of Christian theology and the secular state dominated mediaeval universal and national histories well after the fall of the Western Roman Empire. Any mediaeval library with a modest collection contained Orosius's work, and it found explicit intellectual purchase in England through Alfred the Great, who had it translated into Old English and modified to support his claims to kingship, in Germany through Otto of Freising, who acknowledged his debt to Orosius in his famous work of universal history, in Spain through the double works of the Estoria of Espanna and the General Estoria

Christianity, ed. Susan Boynton and Diane J. Reilly (New York: Columbia University Press, 2011), 87 .

32 See Hervé Inglebert, "Introduction: Late Antique Conceptions of Late Antiquity," in The Oxford Handbook of Late Antiquity, ed. S. F. Johnson (Oxford: Oxford University Press, 2012), 3-28.

33 Jonathan Conant, "Donatism in the Fifth and Sixth Centuries," in The Donatist Schism: Controversy and Contexts, ed. Richard Miles (Liverpool: Liverpool University Press, 2016), $35^{2-} 53$. 
authorized by Alfonso $\mathrm{x}$ of Castile, and in many other regions of Europe. ${ }^{34}$ Thus, the technology of the universal history emerged as a powerful device for authorizing particular local sovereigns: chronometry, chronography, and chronology synthesized into a powerful chronosophy that provided temporal legitimation for over a millennium. ${ }^{35}$

The disappearance of the Western Roman Empire, however, did present a particularly acute problem even for Orosius's paradigm, and provoked much thinking about history itself throughout Europe. The cosmic salvation history of Christianity had matched up so well with the imperial rhetoric of Rome, but the Germanic invasions introduced a discontinuity into the dominant epistemic paradigm. In the end, the four kingdoms schema helped a variety of post-imperial political powers re-create a story that made sense of their world. First was Cassiodorus, who worked as a Roman Senator working as a senior administrative official for the ruling Ostragoth king, Theoderic, in the sixth century CE. Cassiodorus's position likely influenced his choice to frame his work of universal history, the Chronica, as an uninterrupted chain of divinely sanctioned imperial continuity from ancient Rome to the Goth Eutharic's consulship. ${ }^{36}$ This is the earliest known extension of the translatio imperii to a sovereign hailing from a Germanic tribe.

Not everyone agreed: Isidore of Seville, for example, contested the idea that there was a still-existing Roman empire, and supported the diverse local sovereigns who had risen in its place-precisely because the Eastern Roman Emperor Justinian was attempting to conquer Isidore's native Spain. ${ }^{37}$ Thus, the imminent political context of various Christian theological historians

34 See A. Fiebig, "vier tier wilde. Weltdeutung nach Daniel in der 'Kaiserchronik," in Deutsche Literatur und Sprache von 1050-1200: Festschrift für Ursula Hennig zum 65. Geburstag, ed. A. Fiebig and H.-J. Schiewer (Berlin: Akademie Verlag, 1995), 27-49; Francis Leneghan, "Translatio Imperii: The Old English Orosius and the Rise of Wessex," Anglia 133 (2015): 656-705; Ernst Breisach, Historiography: Ancient, Medieval and Modern (Chicago: University of Chicago Press, 1994), 103-104; Rosa M. Rodriguez, "The Pillars of Hercules: The Estoria of Espana (Escorial, Y.I.2) as a Universal Chronicle," in Universal Chronicles in the High Middle Ages, ed. Michele Campopiano and Henry Bainton (Woodbridge: Boydell \& Brewer, 2017), 223-54; and Claudia Wittig, "Political Didacticism in the Twelfth Century: The Middle-High German Kaiserchronik," in Universal Chronicles in the High Middle Ages, ed. Michele Campopiano and Henry Bainton (Woodbridge: Boydell \& Brewer, 2017).

35 H.-W. Goetz, "The Concept of Time in the Historiography of the Eleventh and Twelfth Centuries," in Medieval Concepts of the Past: Ritual, Memory, and Historiography, ed. G. Althoff, J. Fried, and P. J. Geary (Cambridge: Cambridge University Press, 2002), 139-66.

36 See Arne Søby Christensen, Cassiodorus, Jordanes and the History of the Goths: Studies in a Migration Myth (Copenhagen: Museum Tusculanum Press, 2002), 54-83.

37 See Jamie Wood, The Politics of Identity in Visigothic Spain: Religion and Power in the Histories of Isidore of Seville (Leiden: Brill, 2012), 208-30. 
impacted their decisions, as likely did the opinions of their temporal sovereigns. In Eastern Europe, the Byzantine and later Russian empires argued that they were the legitimate successors of Rome within the four kingdoms schema, whereas in the West the courts of Charlemagne and Otto were eager to cast themselves as the legitimate successors of Rome in Orosius's historical framework. For example, Frechulf of Lisieux's ninth century universal Chronicle uses the four kingdoms schema to trace the divine gift of sovereignty from Assyria through the Medes and Persians to the Greeks, then to the Caesars and finally to the Carolingian dynasty. ${ }^{38}$ In the turmoil of Late Antiquity and the transition to the mediaeval period, the chronosophy of the extended four kingdoms schema provided a theological and intellectual grounding for a wide variety of claims to temporal sovereignty, both universal and local. The central motif of the four kingdoms scheme, after all, is the theological explanation of political transition in both a spatial and temporal sense, which worked perfectly to explain the precise turmoil of the early mediaeval period while retaining the implicit salvation history that was important to Christianity. As a result, a new sense of time emerged in the transition from Late Antiquity, which depended on the imperial Roman epitome of time, to new mediaeval sensibilities about time and space.

The Four Kingdoms Schema from Late Antiquity to Mediaeval Europe

I will briefly present a chronosophical representation from the mediaeval period that attempts to summarize the tremendous political impact of the technology of the universal history structured as a four kingdoms schema: namely, the thirteenth century Hereford map. I have chosen this representation because it demonstrates a potential interpretation of the text of the book of Daniel that was actualized fairly consistently throughout the mediaeval period. ${ }^{39}$ This example connects time and space to make narrative sense of the cosmos and universal history after the dissolution of the Roman Empire.

38 See Graeme Ward, "All Roads Lead to Rome? Frechulf of Lisieux, Augustine and Orosius," EME 22 (2014): 492-505.

39 See Mariano Delgado, Klaus Koch, Edgar Marsch, eds., Europa, Tausendjähriges Reich und Neue Welt: zwei Jahrtausende Geschichte und Utopie in der Rezeption des Danielbuches (Stuttgart: Kohlhammer, 2003); Hans Thomas, "Translatio Imperii," Lexikon des Mittelalters, ed. Robert Auty et al. (Munich: Lexma, 1997), 8:944-46; Werner Goez, Translatio Imperii: Ein Beitrag zur Geschichte des Geschichtsdenkens und der politischen Theorien im Mittelalter und in der frühen Neuzeit (Tübingen: Mohr, 1958). 
Maps are never neutral, objective representations of space. ${ }^{40}$ As J. B. Harley has argued, "[b]oth in their selectivity of content and in their signs and styles of representation, maps are a way of conceiving, articulating, and structuring the human world which is biased towards, promoted by, and exerts influence upon particular sets of social relations." ${ }^{41}$ Invariably, maps filter information and impose a particular hermeneutic of time onto space. Moreover, maps always center a particular time - for example, the "age of empires" — and this often reflects a particular political designation. Likewise, chronological charts are never purely temporal: they necessarily center the timelines of particular geographic regions. ${ }^{42}$ Thus, maps are also-always temporal, and chronological charts are also-always spatial, and both reflect political orientations of the one who constructs the visual organization. And in the Mediaeval and Early Modern periods, cartographers and chronographers of the Christian West quite often reflected the political theology of the four kingdoms schema. ${ }^{43}$ Fra Paolino Veneto, an early fourteenth century Minorite friar, explicitly endorsed the crucial importance of the four kingdoms schema for mapmaking:

I think that it is not just difficult but impossible without a world map to make [oneself] an image of, or even for the mind to grasp, what is said of the children and grandchildren of Noah and of the Four Kingdoms and other nations and regions, both in divine and human writings. There is needed moreover a two-fold map, [composed] of painting and writing. Nor will you say one is sufficient without the other, because painting without writing indicates regions or nations unclearly, [and] writing without the aid of painting truly does not mark the boundaries of the provinces of a region.. $.4^{4}$

40 See John Pickles, A History of Spaces: Cartographic Reason, Mapping and the Geo-Coded World (London: Routledge, 2004).

41 J. B. Harley, "Maps, Knowledge, and Power," in The Iconography of Landscape: Essays on the Symbolic Representation, Design, and Use of Past Environments, ed. Denis Cosgrove and Stephen Daniels (Cambridge: Cambridge University Press, 1988), 278. See also Jeremy Crampton and Stuart Elden, eds., Space, Knowledge and Power: Foucault and Geography (Burlington: Ashgate, 2007).

42 See Daniel Rosenberg and Anthony Grafton, Cartographies of Time: A History of the Timeline (New York: Princeton Architectural Press, 2010).

43 Rosenberg and Grafton, Cartographies of Time, $5^{\mathrm{O}}-5^{8}$.

44 Translated and quoted by Jürgen Schulz, "Jacopo de' Barbari's View of Venice: Map Making, City Views, and Moralized Geography before the Year 150o," ArB 6o (1978): 42574, esp. $45^{2}$. 
Why would Fra Paolino claim that one of the most important functions of mediaeval cartographers is to help viewers grasp the meaning of the four kingdoms? To understand, we must revisit Paulus Orosius. In his universal history, Orosius notes the geographic location of Alexander's famed "northern altars" that he built in relation to the four empires schema: "That the Macedonian Empire was in the North is obvious both from its geographical position and the altars of Alexander the Great which stand to this day near the Rhipean Mountains." ${ }^{45}$ Orosius here suggests that "each of the four Empires was thought to have had a monument representative of its position-but Orosius makes no mention of the other three." ${ }^{\prime 6}$ In the developed form of the translatio imperii scheme, found already in the Carolingian era, the idea that the empires were moving from East to West added another directional vector to the four kingdoms schema. ${ }^{47}$

In the mid-twelfth century, the German bishop Otto of Friesing wrote a defining work of mediaeval historiography that explicitly frames the history of the world with the four kingdom schema. ${ }^{48}$ Otto also orients time and the transfer of sacred rule as a movement through space from east to west, and includes the transfer of knowledge (later understood as translatio studii). ${ }^{49}$ Ordericus Vitalis in Normandy and Richard de Bury with Britain are examples

45 Paulus Orosius, The Seven Books of History against the Pagans: The Apology of Paulus Orosius, trans. Irving Woodworth Raymond (New York: Columbia University Press, 1936), 321.

46 Stephen McKenzie, "Conquest Landmarks and the Medieval World Image" (PhD diss., University of Adelaide), 2000, 103.

47 Alciun makes this connection in his Comentarii in Apocalypsin on Rev 7:1-3. See Bruce Eastwood, Ordering the Heavens: Roman Astronomy and Cosmology in the Carolingian Renaissance (Leiden: Brill, 2007), 169-70. Also note the prominent frescoes of the four kingdoms on the walls of Charlemagne's palace at Ingelheim. See Jacob Burckhardt, Italian Renaissance Painting According to Genres, trans. D. Britt and C. Beamish (Los Angeles: Getty, 2005), 68. See also Notker the Stammerer's use of the statue of Daniel 2 in his Notkeri Balbuli Gesta Karoli Magni imperatoris, ed. H. F. Haefele, MG HSRG 12 (Berlin: Weidmann, 1959), 1; and Lewis Thorpe, Einhard and Notker the Stammerer: Two Lives of Charlemagne (Baltimore: Penguin, 1969), 93.

48 On the east-west progression, see Allesandro Scafi, Mapping Paradise: A History of Heaven on Earth (Chicago: University of Chicago Press, 2006), 127. See also R. Deutinger, "Engel oder Wolf? Otto von Freising in den geistigen Auseinandersetzungen seiner Zeit," in Ars und Scientia im Mittelalter und in der Frühen Neuzeit: Ergebnisse interdisziplinärer Forschung: Georg Wieland zum 65. Geburtstag, ed., C. Dietl and D. Helschinger (Tübingen and Basel: Francke, 2002), 31-46.

49 "And let it be observed that because all human learning began in the Orient and will end in the Occident, the mutability and disappearance of all things will be demonstrated" (Otto, Bishop of Freising, The Two Cities: A Chronicle of Universal History to the Year 1146 $A . D$., trans. C. Mierow, ed. A. Evans and C. Knapp [New York: Columbia University Press, 
of other mediaeval historians who agree with Otto of Freising's concept, but each suggests that the movement of empire and learning found its telos in his own emerging nation. ${ }^{50}$

These geographic models of power and knowledge structured the mediaeval practice of constructing universal maps, or mappae mundi. ${ }^{51}$ As Scafi notes, "the importance of the four kingdoms in human history was indicated on mediaeval maps of the world by visual or textual references to their rulers, people, or monuments." ${ }^{2}$ Particular landmarks associated with the four kingdoms on mediaeval maps generally follow Orosius, which was "designed to form a square shape by placing Macedonia and Carthage to the north and south," can be found on many mediaeval maps. ${ }^{53}$ This combination of geography and history was deployed in the service of a particular political theology of mediaeval Europe. As Rudolf Simek notes, mediaeval world maps did not attempt to represent the world by a physically accurate model, and they "were not conceived as an aid for travelers." Instead, these maps of the world "served as physical abbreviations of all reality, incorporating both the material and the spiritual world." 54

For example, let us consider the Hereford map, which dates to the late thirteenth century in England. ${ }^{55}$ It is the largest extant mediaeval map, and hung for centuries unnoticed on the wall of a choir aisle. It is based on earlier theological maps such as the famous map of Beatus of Liebana, found in the codices of his apocalyptic commentary on Daniel and Revelation, but it is much richer in its depictions. ${ }^{56}$ The Hereford map represents four hundred and twenty towns, fifteen biblical events, many varieties of animals and plants as well as important people. At the top of the image is Christ's second coming

2002], 155). On translatio studii, see Ernst F. J. Worstbrock, "Translatio artium," AKG 47 (1965): 1-22.

$50 \quad$ See Jacques Le Goff, Time, Work, and Culture in the Middle Ages, trans. A. Goldhammer (Chicago: University of Chicago Press, 1980), 32-34.

51 See Naomi Reed Kline, Maps of Medieval Thought: The Hereford Paradigm (Woodbridge: Boydell, 2001).

52 Scafi, Mapping Paradise, 128.

53 McKenzie, "Conquest Landmarks," 103.

54 Rudolf Simek, Heaven and Earth in the Middle Ages: The Physical World Before Columbus, trans. A. Hall (Woodbridge: Broydell Press, 1996), 41-43. See also Evelyn Edson, Mapping Time and Space: How Medieval Mapmakers Viewed their World, The British Library Studies in Map History (London: British Library, 1997), 1:2-9.

55 See Scott D. Westrem, The Hereford Map: A Transcription and Translation of the Legends with Commentary (Turnhout: Brepols, 2001).

56 See John Williams, "Isidore, Orosius and the Beatus Map," Imago Mundi 49 (1997): 7-32; Williams, The Illustrated Beatus: A Corpus of the Illustrations in the Commentary on the Apocalypse, 5 vols. (London: Harvey Miller, 1994-2003). 
in judgment over the world, signifying both divine providence and a telos for the structure of the world.

At the top of the Hereford map is a marginal comment: "Orosius' description, from the Ormesta Mundi as is shown within," referring to the work of Orosius, including his historical structuring-device of the four kingdoms schema. ${ }^{57}$ Since the time of Alfred the Great, the Saxons had used Orosius as justification for their claim that they had inherited the mantle of the fourth kingdom after the seeming collapse of the Carolingian empire, so his appearance in the title of the map is not a surprise. ${ }^{58}$ Orosius is ever-present in the Hereford map, as his descriptions of history and geography serve as a major source of information. ${ }^{59}$ Also in the margin are inscriptions that "The orb of the earth began to be surveyed by Julius Caesar," and the names of the surveyors of the east, the north and west, and the south, depicting Roman imperial authority over the globe. In the lower left corner is a picture of the emperor sending forth three commissioners by warrant under the seal of Augustus Caesar (cf. Luke 1-2). As Leneghan explains, "in this vision of world history, God showed His favour to the Romans not only by allowing them to be conquered by a relatively clement Christian people, the Goths, but also by sending His Son to redeem mankind during the Pax Augusta, marking the Romans out as rerum dominos 'masters of the World' (cf. Virgil, Aeneid, I, l. 282)."60

One can read the map as a progression of both geography and chronology, running from east to west. As Peter Barber remarks, the inclusion of "Babylon, Medea (sic), Macedonia, and Rome are intended to recall the four empires which had characterized human history." ${ }^{61}$ These empires are placed on the map roughly along the east-west axis in order of their historical occurrence, moving forward in time from Media in the east to Rome in the west, and beyond to the particular political and ethnic group responsible for the map who are seeking to legitimate their self-understanding of their place in the worldin the case of the Hereford world map, the English.

Babylon and Rome both have special graphic importance on the map, suggesting particular prominence in the English imagination. Their prominence is even more striking because the mapmaker did not depict any German cities on the map-that is, the historical ancestors of the Anglo-Saxons, of which

\footnotetext{
57 Ormesta is an abbreviation of "Or[osii] m[undi h]ist[ori]a" (Kline, Maps of Medieval Thought, 63-64, 184, 222).

58 Leneghan, “Translatio Imperii," 656-701.

59 See Kline, Maps of Medieval Thought, 186.

6o Leneghan, "Translatio Imperii," 663.

61 Peter Barber, "Medieval Maps of the World," in The Hereford World Map: Medieval World Maps and their Context, ed. P. D. A. Harvey (London: The British Library, 2006), 1-44.
} 
they were well aware. ${ }^{62}$ Thus the Hereford map stresses the theological and political construal of the English inheritance and identity, not necessarily their geographical and biological ancestry. This is not the only mappa mundi to reflect Orosius's particular theological geo-chronography: the roughly contemporaneous Ebstorf map parallels the Hereford map, as well. ${ }^{63}$

Thus many mediaeval theologians, historians, cartographers and iconographers conceived of the world as a fundamentally ordered space, in which disorder plays a marginal role. As Emile Mâle noted: "The Middle Ages had a passion for order. They organized art as they had organized dogma, secular learning and society." ${ }^{44}$ Mediaeval chronological charts, as well, seek to make plain the order of human history. ${ }^{65}$ And order suggests some kind of organizing power: namely, a sovereign. A variety of theological temporal schemas such as the six ages of the world were often used as structuring devices throughout the mediaeval period, but it was the four kingdoms schema in particular that combined divine sovereignty, the legitimation of specific secular authorities, and a unified geographic-chronological progression. This precise combination constituted the politics of time in mediaeval Europe.

\section{4 \\ The Four Kingdoms Schema from Mediaeval Europe to the Early Modern Period}

Just as with the shift from Late Antiquity to the Mediaeval period, the series of crises which eventuated in the Early Modern world led to new political realities, a new sense of time and space, new chronometries, new chronologies and a host of new chronosophies. ${ }^{66}$ The story of the transition from the Mediaeval to the Early Modern period can be illuminated in the progression of two chronometric devices which illuminate the shifting role of the four kingdoms schema.

\footnotetext{
62 Leneghan, "Translatio Imperii," 682.

63 See Kline, Maps of Medieval Thought, 220, 239.

64 Emile Mâle, The Gothic Image: Religious Art in France of the Thirteenth Century, trans. Dora Nussey (New York: Harper Torchbooks, 1958), 1.

65 See Rosenberg and Grafton, Cartographies of Time.

66 See David Landes, Revolution in Time: Clocks and the Making of the Modern World (Cambridge: Belknap, 1983); and Amy Boesky, "Giving Time to Women: The Eternizing Project in Early Modern England," in This Doubled Voice: Gendered Writing in Early Modern England, ed. Danielle and Elizabeth Clarke (New York: St. Martin's Press, 200o), 123-41.
} 
The first example, a sundial on the exterior of the Cathedral of Notre-Damede-Strasbourg, was carved in about $1490 .{ }^{67}$ Above the sundial, an astronomer gazes out at the skies, scrutinizing in order to understand the divisions of time, but he serves as a symbol for a technology that had existed for thousands of years. The second time-keeping device, found inside that same cathedral in the city of Strasbourg, dates to the third quarter of the sixteenth century. 68 It is an astronomical clock, and remains a mechanical wonder even today for its extraordinary complexity: it kept track of the planetary orbits, the sun and moon, solar and lunar eclipses, the zodiac, the annual calendar, and more. ${ }^{69}$ In the span of two centuries, the experience of time itself in the city of Strasbourg radically transformed. Strasbourg was not alone: by the sixteenth century, clocks were omnipresent in European urban centers, and had come to replace the sundial not only in technological prowess but more importantly in symbolic significance. ${ }^{70}$ Public clocks represented a shift in the phenomenology and meaning of time, which informed conceptions of sovereignty that emerged in a tumultuous moment in political history.

Sometime in the late-thirteenth or early-fourteenth century, a series of technological innovations made possible a clock mechanism that kept fairly accurate time. ${ }^{71}$ While many of these early marvels were housed in monasteries to help religious orders keep accurate prayer schedules, by 1370 Charles V installed striking clocks in several of his residences and constructed a public clock at the Louvre. Charles then ordered that all the diverse bells of Paris be set according to the clock at the Palais-Royal, the Horloge du Palais. ${ }^{72}$ While the story is complex, one can from that moment trace the development of state control over the maintenance and ordering of time. ${ }^{73}$ According to

67 Rovelli, Order of Time, 59-6o.

68 The first astronomical clock in Strasbourg was built between $135^{2}$ and 1354, but was dismantled in 1572 when the second, much more mechanically and artistically complex astronomical clock began construction.

69 Günther Oestmann, Die Strassburger Münsteruhr: Funktion und Bedeutung eines KosmosModellsdes16.Jahrhunderts, 2nd ed. (Berlin:Verlag fur Geschichte der Naturwissenschaften und der Technik, 200o); Henri Bach, Jean-Pierre Rieb, and Robert Wilhelm, Les trois horloges astronomiques de la Cathédrale de Strasbourg (Strasbourg: Ronald Hirlé, 1992); Henry C. King and John R. Millburn, Geared to the Stars: The Evolution of Planetariums, Orreries, and Astronomical Clocks (Toronto: University of Toronto Press, 1978).

70 See Le Goff, Time, Work, and Culture, 49-50.

71 Gerhard Dohrn-van Rossum, History of the Hour: Clocks and Modern Temporal Orders, trans. Thomas Dunlap (Chicago: University of Chicago Press, 1996), 103-12.

72 Carlo Cippola, Clocks and Culture, 1300-1700 (New York: Norton, 2003), 33-34. But note the critique by Dohrn-van Rossum, History of the Hour, 217-19.

73 Le Goff, Time, Work, and Culture, 49-5o. Note also the caution from Dohrn-van Rossum, History of the Hour, 13, 127. 
Landes, this act underscores the primacy of royal power; as Le Goff concludes, the new technologically measured, rational time thus became the time of the state. ${ }^{74}$ By the early-fifteenth century, regional governments required clocks in the urban centers of Europe by administrative decree.

As Le Goff argues, "The disturbance of the chronological framework in the fourteenth century was also a mental and spiritual disturbance." ${ }^{75}$ European city dwellers now were expected to regulate their activities, their business, and their spiritual lives by the clock. The clock became the foundational political metaphor for the age: society, the state, and the bureaucracy were all now supposed to function like clockwork, individuals and groups became obsessed with saving and investing and measuring time. The divisible moments of the day were more regularly compared to quantities of money. ${ }^{76}$ Some scholars have argued that rationalization of time also led to its secularization, but of course this is not quite true: the sacred intrudes often when a culture attempts to construct a chronosophy. ${ }^{77}$

In Strasbourg, the first astronomical clock was finished in 1352, and was known as the clock of the three Magi. ${ }^{78}$ At noon each day, the mechanism made figures of the magi-known for their knowledge of the heavenly bodies and grasping the significance of time-bowed their heads to Mary. By the 1540s, the first clock had ceased to function. The mathematician Christian Herlin began designing a new astronomical clock, but in 1571 , Herlin passed the responsibility to his student, the scientist and philosopher Conrad Dasypodius, who spent the next four years overseeing its construction. ${ }^{79}$ Dasypodius's astronomical clock was not just a clock: it presented a symbolic chronosophy that strove to represent the political-theological ethos of Dasypodius's era, and portrayed a number of symbolic conceptions of time to that effect. On the different parts of the device, one could find references to the ages of humanity, the basic outline of Christian salvation history, and the four kingdoms from Daniel. ${ }^{80}$ In the lowest register, an image of Germany stood at the center while clock arms measured time in grand scales, including years and ages. In each corner of the frame enclosing this mechanism, one of the four kingdoms was symbolically depicted and labeled: these included Assyria, Persia, Greece and Rome. And to the left of the clock mechanism, adorning the tower for

\footnotetext{
74 Landes, Revolution in Time, 79; Le Goff, Time, Work, Culture, 49-5o.

75 Le Goff, Time, Work, and Culture, 5 o.

76 Le Goff, Time, Work, and Culture, 51-52.

77 Le Goff, Time, Work, and Culture, 36.

78 Oestmann, Die Strassburger Münsteruhr, 15-28.

79 Oestmann, Die Strassburger Münsteruhr, 37-51.

8o Oestmann, Die Strassburger Münsteruhr, 53-84.
} 
the weight drive, is a depiction of the statue from Nebuchadnezzar's dream in Daniel 2. As Anthony Grafton writes:

Dasypodius' work, in short, was not simply a display of the powers of modern science and technology; it was also a miniature cathedral of its own, in which the pious visitor could read the most traditional lessons about the past, the present, and the (rather abbreviated) future of the human race. Nothing mattered more about time, even here, than its end. And no evidence suggests that these images formed a less organic part of Dasypodius' design than the clockwork they concealed and interpreted. ${ }^{81}$

Dasypodius's chronosophy reflects a distinctively Protestant understanding of the four kingdoms schema from Daniel, because by the 157 os Strasbourg had broken with the Roman pontiff. Luther had established a different identification and ordering of the kingdoms, and in particular a new interpretation of the divided fourth empire of iron mixed with clay: to Luther, it represented the confessionally divided Holy Roman Empire, which remained partly Roman Catholic but was now partly Protestant. ${ }^{82}$ The newly solidified opposition to the image of Rome, Martin Luther's new biblical hermeneutics, a renewed sense of eschatology, and a commitment to humanist notions of scholarship led to a drastic revision of mediaeval traditions about the history of world. As Streete comments, "[r]eformed historiography is grounded in an imperially inflected eschatology. It offers a ... rethinking of 'Rome,' ancient and Roman Catholic, an imperial legitimation of the Reformed state and monarch, and a promise of the revelation to come." 83 Whereas the mediaeval monarchs used the four kingdoms schema to reinforce a sense of order and natural, divinely sanctioned universal authority, the Protestant use of the schema tended to focus on rupture, the surrounding threat of subjugation, and the present tumultuous final days.

81 Anthony Grafton, "Chronology and Its Discontents in Renaissance Europe: The Vicissitudes of a Tradition," in Time: Histories and Ethnologies, ed. Diane Owen Hughes and Thomas R. Trautmann (Ann Arbor: University of Michigan Press, 1995), 139-66.

82 See Laurence Dickey, "Translatio Imperii and Translatio Religionis: The 'Geography of Salvation' in Russian and American Messianic Thinking," in The Cultural Gradient: The Transmission of Ideas in Europe, 1789-1991, ed. Catherine Evtuhov and Stephen Kotkin (Lanham: Rowman \& Littlefield, 2002), 13-32.

83 Adrian Streete, Apocalypse and Anti-Catholicism in Seventeenth-Century English Drama (Cambridge: Cambridge University Press, 2017), 34. 
In that sense, early Protestants drew from the reform and apocalyptic movements of the Mediaeval period. ${ }^{84}$ They also returned to ancient sources like Daniel, but cast a wary eye at more traditional modes of interpretation. In terms of political sovereignty, early Protestant interpreters rejected the idea that the four kingdoms formed a continuous, unbroken line that ends by affirming the current local monarch. ${ }^{85}$ Instead, they argued that the four kingdoms represented the awful tyranny of ungodly imperium, and these kingdoms were to be resisted and rejected in favor of a new kind of sovereign - namely Protestant magistrates, who were understood as harbingers of the fifth righteous kingdom. ${ }^{86}$ The Reformers' argument that all four kingdoms of Daniel represent evil opponents, embodied concretely by Papal Rome and the invading Turks, is adumbrated by the Strasbourg Astronomical clock. ${ }^{87}$ The four kingdoms surrounded a calendar that began at the presumed date of creation and was reset every year so that it always projected a century into the future; this calendar also marked days of the week, the month, and feast days. Thus, the mechanical time of merchants, the bureaucratic time of the local state, the legitimating time of imperial monarchs, the cosmic time of scientists, and the eschatological time of salvation history are interlinked in the complex semiotic networks of the Strasbourg clock. In short, it was a machine built to produce the chronosophy of the Early Modern world.

The Strasbourg clock quickly grew famous throughout Europe, and was celebrated in widely circulated woodcuts by Tobias Stimmer, who designed and executed the paintings that adorned the clock itself. The woodcuts featured a poem written by the famous poet Philip Nicodemus Frischlin praising the clock, God's work in salvation history, and Dasypodius's scientific genius, all dedicated to the magistrates and senate of Strasbourg. ${ }^{88}$

84 On reform and biblical apocalypticism, see Matthew Gabriele, "This Time, Maybe This Time: Biblical Commentary, Monastic Historiography, and Lost Cause-ism at the Turn of the First Millennium," in Apocalypse and Reform from Late Antiquity to the Middle Ages, ed. Matthew Gabriele and James T. Palmer (London: Routledge, 2019), 183-204.

85 Euan Cameron, "Cosmic Time and the Theological View of World History," ITQ 77 (2012): 349-64.

86 See Ernst Breisach, Historiography: Ancient, Medieval, and Modern, 3rd ed. (Chicago: University of Chicago Press, 2007), 163.

87 See Heinrich Bornkamm, Luther and the Old Testament, trans. Eric W. and Ruth C. Gritsch (Mifflingtown, PA: Sigler Press, 1997), 68.

88 F. C. Haber, "The Cathedral Clock and the Cosmological Clock Metaphor," in The Study of Time II: Proceedings of the Second Conference of the International Society for the Study of Time, Late Yamanaka-Japan, ed. J. T. Fraser and N. Lawrence (Springer: New York, 1975), 409 . 
In the same year that the clock was completed, a second apocalyptic vision attributed to the pseudonymous Wilhelm Friess, but likely written by the wellknown Strasbourg-based printer, Johann Fischart, appeared. ${ }^{89}$ Friess's first vision, published in Antwerp in the 1550s during the wars of religion, was proProtestant propaganda set within the frame of eschatological, quasi-scientific astrology; this propaganda was so powerful that two printers responsible for disseminating it were executed. ${ }^{90}$ After Friess's reported death, many new prophecies written in his name began to be published throughout the continent. By 1574, when a major new prophecy attributed to Friess emerged in Calvinist Strasbourg, the astronomical clock had primed the citizenry for a new round of astronomical prophecy. As Jonathan Green explains, the Friess prophecy of 1574 presents a nightmare vision of demonic armies invading Germany from all sides. Previous visions attributed to Friess also described an invasion of Protestant lands. In the 1574 version, however, the prophecy depicts "an invasion approaching from four directions," corresponding to the four empires depicted on the Strasbourg astronomical clock-which was the source for the astrological knowledge in the text. ${ }^{91}$ The concern with invading armies was not fictional, either: the newly crowned Henry III of France terrified the Alsatian Calvinists. Thus, the Friess prophecy of 1574 "can be seen as an apocalyptic ekphrasis inspired by the astronomical clock in Strasbourg."92 In its far-reaching influence and its ability to combine the political, scientific, and apocalyptic, Dasypodius's timepiece reveals something of the distinctive Early Modern politics of time.

There are other examples of very different uses of the four kingdoms even in Protestant Germany — the Lüneberger Spiegel of 1587 , for example, that Sophie of Brandenburg gave to her son, Christian II, on the eve of his accession to elector, or the early seventeenth century western facade of the Nuremberg Rathaus, which reimagined the history of sovereignty eventuating not in a royal palace, but in a city hall that emphasized the local self-determination of a free city. ${ }^{93}$ Several revolutionaries in the Early Modern period, such as the Fifth Monarchy Men in England or Thomas Müntzer in Germany, draw upon the four kingdom schema to represent a new conception of time: namely, the

\footnotetext{
89 Jonathan Green, The Strange and Terrible Visions of Wilhelm Friess: The Paths of Prophecy in Reformation Europe (Ann Arbor: University of Michigan Press, 2014), 107-109.

90 Green, Strange and Terrible Visions, $1-35$.

91 Green, Strange and Terrible Visions, 77, 109.

92 Green, Strange and Terrible Visions, 109.

93 See Hans Schröder, Dirch Utermarke ein Hamburger Goldschmied der Renaissance (Hamburg: Museum für Hamburgische Geschichte, 1939), 100-102; Ernst Mummenhoff, Das Rathaus in Nürnberg (Nürburg: J. H. Schrag, 1891), 133-38.
} 
radical interruption that rejected sovereign control over time in an attempt to create the possibility of a new order. ${ }^{94}$ It is not a surprise that they emphasize the breaking of the statue and the discontinuous eruption of a kingdom of the righteous. Thomas Müntzer in particular attacked the princes of Saxony with a schema that they interpreted in a very different way: to Müntzer, the princes were the weak and broken clay toes, unable to defend themselves against the stone's impending strike. ${ }^{95}$ These re-imaginings of the four kingdoms schema, and many others, were made possible by the cultural, political and theological ruptures of the Early Modern period.

\section{Conclusion: The Four Kingdoms in Enlightenment and} Post-Enlightenment Thought

While space-time precludes me from pursuing this historical investigation much further, I will conclude by noting that the Enlightenment introduced another epistemic, political and theological shift that opened room for still more interpretations of the four kingdoms schema, while foreclosing others. Perhaps the dominant image of the concept of time in the transition to the Enlightenment is the work of scientific historiography that attempts to understand the past dispassionately and represent it as it "actually was."

The French Encyclopedia, published between $175^{1}$ and $177^{2}$ by Diderot and d'Alembert, attempted to synthesize all the production of knowledge of the past and present. Jacques Le Goff sees this event as so important that it marks the final transition away from the mediaeval world, and thus "the end of one period and the beginning of another."96 Yet, as Le Goff points out, scholars embodying the principles of the Enlightenment still draw upon the four kingdoms schema even after it had been decisively attacked by Jean Bodin, among others. ${ }^{97}$

94 Thomas Rahn, "Geschichte gedächtnis am Körper: Furstliche merkund Mediationsbilder nach Weltreiche Prophetie des zweite Buches Daniel," in Seelenmaschinen: Gattungstraditionen, Funktionen und Leistunggrenzen der Mnemotechniken vom späten Mittelalter bis zum Beginn der Moderne, ed. Jorg Jochen Berns and Wolfgang Neuber (Vienna: Böhlau Verlag, 200o), 521-61; Oliver Cromwell, Speeches of Oliver Cromwell, 1644-1658, ed. Charles Stainer (Oxford: Oxford University Press, 1901), 113-14.

95 Thomas Müntzer, Revelation and Revolution: Basic Writings of Thomas Müntzer, ed. and trans. M. Baylor (Cranbury: Associated University Presses, 1993), 108-109.

96 Le Goff, Must We Divide History, 89.

97 See Cameron, "Cosmic Time" and Jean Bodin, Methodus ad facile historiarum cognitionem (Heidelberg: Heredes Ionannis Mareschalli Lugdunensis, 1591), 416-33. 
Even Voltaire used a fourfold division of time in his Le siècle de Louis XIV (1751). He wrote, seemingly unironically, "whosoever has taste, will find but four ages in the history of the world."98 For Voltaire, these four ages coincide with peaks of human achievement: first in ancient Greece, then Caesar in Rome, then the Renaissance, and then, last but certainly not least, Louis XIV. Perhaps Voltaire rejected all kinds of superstitions of the past, but he could not escape the political legitimation of translatio imperii et studii. Hegel could not escape it, either, as he divided history into four empires: Oriental, Greek, Roman and Germanic. Even Foucault, who named three crucial ages in history: the Renaissance, the age of Reason from Descartes to Revolution, then historicist scholarship of the twentieth century, and then added a fourth and golden era, "a future, starting now," of discursive analysis. ${ }^{99}$ Perhaps these enlightened scholars drew upon the schema for two interlinked reasons: first, articulation must precede any analysis, and second, any attempt to synthesize history requires the use or creation of a meaningful chronosophy. Meaning does not reside in pure objective fact: it is the result of a hermeneutic, and it must draw on pre-existent cultural reservoirs, at least to some degree, to make sense. Doubtless, much more work is required to explore more carefully how the epistemic, political and theological ruptures at the boundaries of historical periods lead to re-interpretation and redeployment of the four kingdoms schema. But that will have to wait for another day.

\section{Bibliography}

Bach, Henri, Jean-Pierre Rieb, and Robert Wilhelm. Les trois horloges astronomiques de la Cathédrale de Strasbourg. Strasbourg: Ronald Hirlé, 1992.

Ballentine, Samuel. "The Future Beyond the End: Lessons from History by Herodotus and Daniel." PRSt 43 (2016): 145-59.

Barber, Peter. "Medieval Maps of the World." Pages 1-44 in The Hereford World Map: Medieval World Maps and their Context. Edited by P. D. A. Harvey. London: The British Library, 2006.

Bidmead, Julye. The Akitu Festival: Religious Continuity and Royal Legitimation in Mesopotamia. Piscataway: Gorgias, 2014.

98 See Le Goff, Must We Divide History, 11.

99 See John Urquhart, "Daniel and Hegel: History and Prophecy," The Christian Monthly and Family Treasury (London: T. Nelson and Sons, 1881), 556-61; and Ian Hacking, Historical Ontology (Cambridge, MA: Harvard University Press, 2002), 77-78. 
Bloch, Ernst. "Nonsynchronism and the Obligation to Its Dialectics." Translated by Mark Ritter. New German Critique 11 (1977): 22-38.

Bodin, Jean. Methodus ad facile historiarum cognitionem. Heidelberg: Heredes Ionannis Mareschalli Lugdunensis, 1591.

Boesky, Amy. "Giving Time to Women:The Eternizing Project in Early Modern England.” Pages 123-41 in This Doubled Voice: Gendered Writing in Early Modern England. Edited by Danielle and Elizabeth Clarke. New York: St. Martin's Press, 2000.

Bornkamm, Heinrich. Luther and the Old Testament. Translated by Eric W. and Ruth C. Gritsch. Mifflingtown, PA: Sigler Press, 1997.

Breed, Brennan. "Daniel's Four Kingdoms Schema: A History of Re-writing World History." Int 71 (2017): 178-89.

Breed, Brennan. Nomadic Text:A Theory of Biblical Reception History. ISBL. Bloomington: Indiana University Press, 2014.

Breisach, Ernst. Historiography: Ancient, Medieval and Modern. Chicago: University of Chicago Press, 1994.

Breisach, Ernst. Historiography: Ancient, Medieval, and Modern. 3rd edition. Chicago: University of Chicago Press, 2007.

Brettler, Marc. "Cyclical and Teleological Time in the Hebrew Bible." Pages 111-28 in Time and Temporality in the Ancient World. Edited by R. M. Rosen. Philadelphia: University of Pennsylvania Museum of Archaeology and Anthropology, 2004.

Brin, Gershon. The Concept of Time in the Bible and the Dead Sea Scrolls. STDJ 39. Leiden: Brill, 2001.

Bundvad, Mette. "Defending the Concept of Time in the Hebrew Bible." sJot 28 (2014): 278-95.

Burckhardt, Jacob. Italian Renaissance Painting According to Genres. Translated by D. Britt and C. Beamish. Los Angeles: Getty, 2005.

Cameron, Euan. "Cosmic Time and the Theological View of World History." ITQ 77 (2012): 349-64.

Chakrabarty, Dipesh. Provincializing Europe: Postcolonial Thought and Historical Difference. Princeton: Princeton University Press, 2000.

Christensen, Arne Søby. Cassiodorus, Jordanes and the History of the Goths: Studies in a Migration Myth. Copenhagen: Museum Tusculanum Press, 2002.

Cippola, Carlo. Clocks and Culture, 1300-1700. New York: Norton, 2003.

Conant, Jonathan. "Donatism in the Fifth and Sixth Centuries." Pages $345^{-61}$ in The Donatist Schism: Controversy and Contexts. Edited by Richard Miles. Liverpool: Liverpool University Press, 2016.

Crampton, Jeremy and Stuart Elden, eds. Space, Knowledge and Power: Foucault and Geography. Burlington: Ashgate, 2007.

Cromwell, Oliver. Speeches of Oliver Cromwell, 1644-1658. Edited by Charles Stainer. Oxford: Oxford University Press, 1901. 
Davis, Kathleen. Periodization and Sovereignty: How Ideas of Feudalism and Secularization Govern the Politics of Time. Philadelphia: University of Pennsylvania Press, 2008.

Delgado, Mariano, Klaus Koch, and Edgar Marsch, eds. Europa, Tausendjähriges Reich und Neue Welt: zwei Jahrtausende Geschichte und Utopie in der Rezeption des Danielbuches. Stuttgart: Kohlhammer, 2003.

Deutinger,R. "Engel oderWolf? OttovonFreising in dengeistigen Auseinandersetzungen seiner Zeit." Pages 31-46 in Ars und Scientia im Mittelalter und in der Frühen Neuzeit: Ergebnisse interdisziplinärer Forschung: Georg Wieland zum 65. Geburtstag. Edited by C. Dietl and D. Helschinger. Tübingen and Basel: Francke, 2002.

Dickey, Laurence. "Translatio Imperii and Translatio Religionis: The 'Geography of Salvation' in Russian and American Messianic Thinking." Pages 13-32 in The Cultural Gradient: The Transmission of Ideas in Europe, 1789-1991. Edited by Catherine Evtuhov and Stephen Kotkin. Lanham: Rowman \& Littlefield, 2002.

Dohrn-van Rossum, Gerhard. History of the Hour: Clocks and Modern Temporal Orders. Translated by Thomas Dunlap. Chicago: University of Chicago Press, 1996.

Eastwood, Bruce. Ordering the Heavens: Roman Astronomy and Cosmology in the Carolingian Renaissance. Leiden: Brill, 2007.

Edson, Evelyn. Mapping Time and Space: How Medieval Mapmakers Viewed their World. The British Library Studies in Map History. London: British Library, 1997.

Fiebig, A. "vier tier wilde. Weltdeutung nach Daniel in der 'Kaiserchronik." Pages 27-49 in Deutsche Literatur und Sprache von 1050-1200: Festschrift für Ursula Hennig zum 65. Geburstag. Edited by A. Fiebig and H.-J. Schiewer. Berlin: Akademie Verlag, 1995.

Flusser, David. "The Four Empires in the Fourth Sibyl and in the Book of Daniel." IOS 2 (1972): 148-75.

Gabriele, Matthew. "This Time, Maybe This Time: Biblical Commentary, Monastic Historiography, and Lost Cause-ism at the Turn of the First Millennium." Pages 183204 in Apocalypse and Reform from Late Antiquity to the Middle Ages. Edited by Matthew Gabriele and James T. Palmer. London: Routledge, 2019.

Goetz, H.-W. "The Concept of Time in the Historiography of the Eleventh and Twelfth Centuries." Pages 139-66 in Medieval Concepts of the Past: Ritual, Memory, and Historiography. Edited by G. Althoff, J. Fried, and P. J. Geary. Cambridge: Cambridge University Press, 2002.

Goez, Werner. Translatio Imperii: Ein Beitrag zur Geschichte des Geschichtsdenkens und der politischen Theorien im Mittelalter und in der frühen Neuzeit. Tübingen: Mohr, 1958.

Le Goff, Jacques. Time, Work, and Culture in the Middle Ages. Translated by A. Goldhammer. Chicago: University of Chicago Press, 1980.

Le Goff, Jacques. Must We Divide History Into Periods? Translated by Malcolm DeBevoise. New York: Columbia University Press, 2017. 
Grafton, Anthony. "Chronology and Its Discontents in Renaissance Europe: The Vicissitudes of a Tradition." Pages 139-66 in Time: Histories and Ethnologies. Edited by Diane Owen Hughes and Thomas R. Trautmann. Ann Arbor: University of Michigan Press, 1995.

Green, Jonathan. The Strange and Terrible Visions of Wilhelm Friess: The Paths of Prophecy in Reformation Europe. Ann Arbor: University of Michigan Press, 2014.

Haber, F. C. "The Cathedral Clock and the Cosmological Clock Metaphor." Pages 399416 in The Study of Time II: Proceedings of the Second Conference of the International Society for the Study of Time, Late Yamanaka-Japan. Edited by J. T. Fraser and N. Lawrence. Springer: New York, 1975.

Hacking, Ian. Historical Ontology. Cambridge, MA: Harvard University Press, 2002.

Harley, J. B. "Maps, Knowledge, and Power." Pages 277-312 in The Iconography of Landscape: Essays on the Symbolic Representation, Design, and Use of Past Environments. Edited by Denis Cosgrove and Stephen Daniels. Cambridge: Cambridge University Press, 1988.

Harris, Jennifer. "The Bible and the Meaning of History in the Middle Ages." Pages 84-104 in The Practice of the Bible in the Middle Ages: Production, Reception, and Performance in Western Christianity. Edited by Susan Boynton and Diane J. Reilly. New York: Columbia University Press, 2011.

Holford-Strevens, Leofranc. The History of Time: A Very Short Introduction. Oxford: Oxford University Press, 2005.

Inglebert, Hervé. "Introduction: Late Antique Conceptions of Late Antiquity." Pages $3^{-28}$ in The Oxford Handbook of Late Antiquity. Edited by S. F. Johnson. Oxford: Oxford University Press, 2012.

Jameson, Fredric. The Political Unconscious: Narrative as a Socially Symbolic Act. Ithaca: Cornell University Press, 1982.

Kawashima, Robert. Biblical Narrative and the Death of the Rhapsode. IS BL. Bloomington: Indiana University Press, 2004.

King, Henry C. and John R. Millburn. Geared to the Stars: The Evolution of Planetariums, Orreries, and Astronomical Clocks. Toronto: University of Toronto Press, 1978.

Kline, Naomi Reed. Maps of Medieval Thought. Woodbridge: Boydell Press, 2001.

Landes, David. Revolution in Time: Clocks and the Making of the Modern World. Cambridge: Belknap, 1983 .

Lapin, Hayim. Rabbis as Romans: The Rabbinic Movement in Palestine, 100-40o CE. Oxford: Oxford University Press, 2012.

Leneghan, Francis. "Translatio Imperii: The Old English Orosius and the Rise of Wessex." Anglia 133 (2015): 656-705.

Luhmann, Nicholas. "Kultur Als Historischer Begriff." Pages31-54in Gesellschaftsstruktur und Semantik: Studien zur Wissenssoziologie der modernen Gesellschaft: Band 4. Frankfurt: Surhkamp, 1995. 
Mâle, Emile. The Gothic Image: Religious Art in France of the Thirteenth Century. Translated by Dora Nussey. New York: Harper Torchbooks, $195^{8}$.

McKenzie, Stephen. "Conquest Landmarks and the Medieval World Image." PhD diss., University of Adelaide, 2000.

Mendels, Doron. "The Five Empires: A Note on a Hellenistic Topos." AJP 102 (1981): 330-37.

Momigliano, Arnaldo. "The Origins of Universal History." Pages 133-55 in The Poet and the Historian: Essays in Literary and Historical Biblical Criticism. Edited by R. Friedman. HSs 26. Chico: Scholars Press, 1983.

Müntzer, Thomas. Revelation and Revolution:Basic Writings of Thomas Müntzer. Edited and translated by M. Baylor. Cranbury: Associated University Presses, 1993.

Mummenhoff, Ernst. Das Rathaus in Nürnberg. Nürburg: J. H. Schrag, 1891.

Newsom, Carol A. "Rhyme and Reason: The Historical Résumé in Israelite and Early Jewish Thought." Pages 215-33 in Congress Volume Leiden 2004. Edited by A. Lemaire. VTSup 109. Leiden: Brill, 2006.

Newsom, Carol A. with Brennan Breed. Daniel: A Commentary. otL. Louisville: Westminster John Knox, 2014.

Newton-Smith, W. H. The Structure of Time. London: Routledge \& Kegan Paul, 198o.

Niskanen, Paul. The Human and the Divine in History: Herodotus and the Book of Daniel. JSOTSup 396. London: T\&T Clark, 2004.

Notker the Stammerer. Notkeri Balbuli Gesta Karoli Magni imperatoris. Edited by H. F. Haefele. MG HS RG 12. Berlin: Weidmann, 1959.

Oegema, Gerbern S. Early Judaism and Modern Culture: Literature and Theology. Grand Rapids: Eerdmans, 2011.

Oestmann, Günther. Die Strassburger Münsteruhr: Funktion und Bedeutung eines Kosmos-Modells des 16. Jahrhunderts. 2nd ed. Berlin: Verlag fur Geschichte der Naturwissenschaften und der Technik, 2000.

Otto, Bishop of Freising. The Two Cities: A Chronicle of Universal History to the Year 1146 A.D. Translated by C. Mierow. Edited by A. Evans and C. Knapp. New York: Columbia University Press, 2002.

Paulus Orosius. The Seven Books of History against the Pagans: The Apology of Paulus Orosius. Translated by Irving Woodworth Raymond. New York: Columbia University Press, 1936.

Pickles, John. A History of Spaces: Cartographic Reason, Mapping and the Geo-Coded World. London: Routledge, 2004.

Podskalsky, Gerhard. Byzantinische Reichseschatologie: Die Periodisierung der Weltgeschichte in den vier Grossreichen (Dan 2 und 7) und dem tausendjährigen Friedensreiche (Apok. 20). Munich: Fink, 1972.

Pomian, Krzysztof. “La crise de l'avenir" Le Débat 7 (1980): 5-17.

Pomian, Krzysztof. L'ordre du temps, Bibliothèque des Histoires. Paris: Gallimard, 1984. 
Pomian, Krzysztof. "Astrology as a Naturalistic Theology of History." Pages 29-43 in "Astrologi Hallucinati:" Stars and the End of the World in Luther's Time. Edited by Paola Zambelli. Berlin: Walter de Gruyter, 1986.

Rahn, Thomas. "Geschichte gedächtnis am Körper: Furstliche merkund Mediationsbilder nach Weltreiche Prophetie des zweite Buches Daniel." Pages 521-61 in Seelenmaschinen: Gattungstraditionen, Funktionen und Leistunggrenzen der Mnemotechniken vom späten Mittelalter bis zum Beginn der Moderne. Edited by Jorg Jochen Berns and Wolfgang Neuber. Vienna: Böhlau Verlag, 2000.

Rodriguez, Rosa M. "The Pillars of Hercules: The Estoria of Espana (Escorial, Y.I.2) as a Universal Chronicle." Pages 223-54 in Universal Chronicles in the High Middle Ages. Edited by Michele Campopiano and Henry Bainton. Woodbridge: Boydell \& Brewer, 2017.

Rosenberg, Daniel and Anthony Grafton. Cartographies of Time: A History of the Timeline. New York: Princeton Architectural Press, 2010.

Rovelli, Carlo. The Order of Time. Translated by S. Carnell and E. Segre. New York: Riverhead, 2018.

Scafi, Allesandro. Mapping Paradise: A History of Heaven on Earth. Chicago: University of Chicago Press, 2006.

Schröder, Hans. Dirch Utermarke ein Hamburger Goldschmied der Renaissance. Hamburg: Museum für Hamburgische Geschichte, 1939.

Schulz, Jürgen. “Jacopo de' Barbari's View of Venice: Map Making, City Views, and Moralized Geography before the Year 150o." ArB 6o (1978): 425-74.

Schwartz, Seth. "Rabbinic Culture' and Roman Culture." Pages 283-99 in Rabbinic Texts and the History of Late-Roman Palestine. Edited by Martin Goodman and Philip Alexander. Oxford: Oxford University Press, 2010.

Simek, Rudolf. Heaven and Earth in the Middle Ages: The Physical World Before Columbus. Translated by A. Hall. Woodbridge: Broydell Press, 1996.

Spencer-Brown, G. Laws of Form. London: George Allen \& Unwin, 1969.

Streete, Adrian. Apocalypse and Anti-Catholicism in Seventeenth-Century English Drama. Cambridge: Cambridge University Press, 2017.

Swain, Joseph. "The Theory of the Four Monarchies: Opposition History under the Roman Empire." CP 35 (1940): 1-21.

Thomas, Hans. "Translatio Imperii." Pages 944-46 in Lexikon des Mittelalters. Vol. 8. Edited by Robert Auty et al. Munich: Lexma, 1997.

Thorpe, Lewis. Einhard and Notker the Stammerer:Two Lives of Charlemagne. Baltimore: Penguin, 1969 .

Urquhart, John. "Daniel and Hegel: History and Prophecy." Pages 556-61 in The Christian Monthly and Family Treasury. London: T. Nelson and Sons, 1881.

Ward, Graeme. "All Roads Lead to Rome? Frechulf of Lisieux, Augustine and Orosius." EME 22 (2014): 492-505. 
Westrem, Scott D. The Hereford Map: A Transcription and Translation of the Legends with Commentary. Turnhout: Brepols, 2001.

Wiesehöfer, Josef. “Vom 'oberen Asien' zur 'gesamten bewohnten Welt': Die hellenistiche-römischeWeltreiche-Theorie.” Pages 66-83 in Europa, Tausendjähriges Reich und Neue Welt: Zwei Jahrtausende Geschichte und Utopie in der Rezeption des Danielbuches. Edited by Mariano Delgado, Klaus Koch, and Edgar Marsch. Stuttgart: Universitätsverlag Freiburg Schweiz, 2003.

Williams, John. "Isidore, Orosius and the Beatus Map." Imago Mundi 49 (1997): 7-32.

Williams, John. The Illustrated Beatus: A Corpus of the Illustrations in the Commentary on the Apocalypse. 5 vols. London: Harvey Miller, 1994-2003.

Wittig, Claudia. "Political Didacticism in the Twelfth Century: The Middle-High German Kaiserchronik." Pages 95-120 in Universal Chronicles in the High Middle Ages. Edited by Michele Campopiano and Henry Bainton. Woodbridge: Boydell \& Brewer, 2017.

Wood, Jamie. The Politics of Identity in Visigothic Spain: Religion and Power in the Histories of Isidore of Seville. Leiden: Brill, 2012.

Worstbrock, Ernst F. J. “Translatio artium.” AKG 47 (1965): 1-22. 